\title{
Companions of the Peace:
}

Diaries and Letters of Monica Storrs, 1931-1939

In 1929 a cultured English gentlewoman arrived in the barely settled wilderness of northern British Columbia as an Anglican missionary, intending to assuage her sense of duty by staying for one year. She stayed for twenty-one. The years covered by Monica Storrs's journal entries (1931-9) were at times unbearably hard, the depression compounding what was already a demanding existence. She and the group of women she lived with, the Companions of the Peace, were sent out as 'missionaries of empire.' As the journals progress, Storrs's droll British wit persists but her imperialistic attitude softens as her work draws her into the lives around her. Expanding on the initial mandate to start Sunday schools, foster contact with women, and perform church services, she became involved in assembling libraries, lending money for seed grain, financing medical assistance, and organizing theatrical performances and poetry contests. After her death even the non-British inhabitants of the Peace River district described her as 'one of us.'

Helped by the judicious editing of historian Vera Fast, these penetrating journal entries make for an unusually absorbing read, with rare details for scholars of British imperialism, Canadian pioneering, and women's life writing, but with enough story and humour to engage any reader.

VERA FAST is a retired historian/archivist living in Manitoba. She also assisted in the book God's Galloping Girl: The Peace River Diaries of Monica Storrs, 1929-1931. 
This page intentionally left blank 


\section{Companions of the Peace}

Diaries and Letters

of Monica Storrs, 1931-1939

Edited by Vera K. Fast

With an introduction by Vera K. Fast and Mary Kinnear

UNIVERSITY OF TORONTO PRESS

Toronto Buffalo London 


\section{www.utppublishing.com}

(C) University of Toronto Press Incorporated 1999

Toronto Buffalo London

Printed in Canada

ISBN 0-8020-4474-3 (cloth)

ISBN 0-8020-8254-8 (paper)

(6)

Printed on acid-free paper

Canadian Cataloguing in Publication Data

Storrs, Monica, $1888-1967$

Companions of the Peace : diaries and letters of

Monica Storrs, 1931-1939

Includes bibliographical references and index.

ISBN 0-8020-4474-3 (bound) ISBN 0-8020-8254-8 (pbk.)

1. Storrs, Monica, 1888-1967 - Diaries. 2. Storrs, Monica, 1888-1967-Correspondence. 3. Companions of the

Peace. 4. Anglican Church of Canada - Biography.

5. Peace River (B.C. : Regional district) - History.

6. Frontier and pioneer life - British Columbia - Peace

River (Regional district). I. Fast, Vera K, 1929- . II. Title

FC3843.3.S86A3 1999 971.1'8703'092 C98-932865-1

F1089.P3S86 1999

University of Toronto Press acknowledges the financial assistance to its publishing program of the Canada Council for the Arts and the Ontario Arts Council. 